who has recently retired from the post of secretary after forty-three years' service with the Royal Commission. Since the awards were inaugurated in 1891, there have been more than five hundred scholars from Great Britain and all parts of the Empire. Most of them have studied in Great Britain and have been grateful for the friendly help given to them by Sir Evelyn Shaw. The presentation consisted of an album containing the signed photographs of 330 'old scholars' from all parts of the world, and a gold coin, dated 40 B.c. and bearing the portraits of Marc Antony and the young Octavius, chosen by Sir Evelyn for his collection. Sir Robert Robinson, chairman of the Science Scholarships Committee of the Royal Commission, and himself a former ' 1851 ' scholar, was unavoidably prevented from being present, and sent a goodwill message. The presentation was made on behalf of his fellow scholars by Prof. E. N. da C. Andrade, who expressed the esteem and affection felt for Sir Evelyn by all who had. come into contact with him.

\section{Trees and Shrubs as Animal Fodder}

THE extent to which animals are dependent on shrubs and trees for fodder is probably not fully realized by those accustomed to associate grazing with true grass or grass-legume pastures, ranges or steppes. The information, however, provided in Joint Publication No. 10, "The Use and Misuse of Shrubs and Trees as Fodder", published by three of the Imperial Agricultural Bureaux (Pastures and Field Crops, Forestry, and Animal Nutrition, respectively) leaves no doubt as to the magnitude of the subject. Over large areas, particularly those with semi-arid climates, in Australia, Africa, India, the U.S.S.R., United States of America and lands in the Mediterranean region, woody plants provide the chief source of food for the numerous low-grade animals kept for the wool, hides and even meat they produce. Most of these regions suffer from gross over-stocking, with a resultant deterioration in the vegetative cover, which in its turn gives rise to serious soil erosion. The problems are numerous, and their solution by no means similar in different parts of the world; but the breeding of better-class animals and a reduction in their numbers should both check the soil erosion and make it economically advantageous to grow improved types of fodder. The best type of management of shrub-tree associations has yet to be found. Experiences with restricted seasonal grazing, reclamation work by re-seeding, and direct shrub cultivation are described and the problems of forest grazing discussed. Bush encroachment on grazing land offers serious difficulty in some countries, and various control measures are being tried for the eradication of undesirable species. As regards nutritive value, the chemical composition and digestibility of some thousand samples of shrubs and trees are tabulated; it is significant that, compared with grassland, the values fluctuate little with season. so that they are of special value in times of drought when indigenous grasses are at their lowest nutritive level. The publication, which contains seventy illustrations, can be obtained from the Imperial Agricultural Bureaux, Central Sales Branch, Penglais, Aberystwyth, Great Britain (9s. net).

\section{Agriculture in Northern Ireland}

IN 1943 an Agricultural Enquiry Committee was set up to report on the future of agriculture in Northern Ireland, and interim reports on transport and rural housing appeared in 1943 and 1944. The full report has now been published (H.M. Stationery Office. $3 s, 6 d$. net) and is divided into five main sections, dealing respectively with agricultural policy and production, marketing and processing, education and research, services ancillary to agriculture, and social conditions and the agricultural community. In view of its geographical position and climate, concentration on the production of livestock and livestock products is recommended as a long-term policy. Closely correlated with this is the need for improvement in the grassland, and to carry this out, the establishment of an experimental farm in County Fermanagh is suggested, and the periodic breaking up of the pastures strongly advocated. As regards marketing, the Committee is of the opinion that the Government should continue its policy of guaranteed prices for all major farm products, such prices being based on those considered necessary to call forth the production required, the Exchequer bearing the cost of any subsidies that may be needed. Considerable reorganisation is proposed in the sphere of education, while as regards research, investigations on the nutritive value of grassland, animal breeding and veterinary problems are of special importance to bring the work into line with the general agricultural policy outlined above. Adequate ancillary services are an essential feature, and attention is directed to the need for a satisfactory system of land tenure, and better electricity and water supplies, drainage and sewage schemes. The concluding section of the report puts forward a proposal for the establishment of a Central Agricultural Council, based on existing organisations, which should act as a corporate body for the promotion of the welfare of the agricultural industry and the improvement of social conditions for the rural population.

\section{The Scottish Plant Breeding Station}

THE twenty-sixth annual report of the director of the Scottish Society for Research in Plant Breeding provides much evidence of the value of research for agriculture. The Society is in a healthy state, having received a large number of subscription members during the year. New varieties of oats, barley, swedes, grasses and kales are either in commerce or will shortly be released. Three lines of work at the Station are of particular interest. The investigations upon virus diseases and blight of the potato have reached the stage at which the breeding of immune or resistant varieties may be directed. Dr. Gregor has shown that local races of grasses are often of considerable value as source material for breeding in the same way as the ancient local strains of oats and barley were of advantage in the eighteenth century. The genecological studies originally made upon Plantago are therefore bearing fruit in agriculture. The director, Mr. W. Robb, has been selecting suitable strains from among more than 15,000 hybrids of oats with the view of combining stiff straw, and freedom from lodging, with high yields. As the result of negotiations between the Society and other bodies it will be possible to enlarge the grounds and the activities in the near future.

\section{An Electric Heater for Flasks}

An electric 'mantle' for the heating of flasks, termed an 'Isomantle', has recently been introduced into Great Britain by Messrs. Towers and Co., Ltd., of Widnes. It consists essentially of a tough, double-walled, glasscloth shroud, hemispherical in shape and carrying a 